\title{
KEPEMIMPINAN KEPALA SEKOLAH, LINGKUNGAN KERJA, MOTIVASI DAN PROFESIONALISME GURU PAUD DI KECAMATAN SUBANG, KABUPATEN SUBANG
}

\author{
Lilis Dini Hayati ${ }^{1}$, Farida Yuliaty ${ }^{2}$, Didin Saepudin ${ }^{3}$ \\ ${ }^{1,2,3}$ Universitas Sangga Buana \\ ${ }^{1}$ korespondensi: lisdini510@gmail.com
}

\begin{abstract}
The Purpose of this research is to analize and to know partially and simultaneously the influence of principal, work environment, and motivation to professionalism of preschool teacher. This research use all preschool teachers as population in Subang subdistrict, Subang, that approximately 238 people. With using slovin fotmula as proportional random sample, that results 150 nursery teachers as a sample in this research. The research method that used in this research is descriptive quantitative and verificative, therefore the data analysis used Multiple Linear Regression. The hypothesis test showed that (1) Leadership the principal affected positively and significantly to professionalism of preschool tearchers. (2) Work environment affected positively and significantly to professionalism of preschool teacher.(3) Motivation affected positively and significantly to professionalism of preschool teacher and (4) The leadership of the primcipal affected positive and significantly to preschool teacher by $64,7 \%$ and else affected by various factors outside this research.
\end{abstract}

Keywords: Leadership Principal, Work environment, Motivation, Professionalism of Preschool Teachers

\begin{abstract}
ABSTRAK
Tujuan dalam penelitian ini adalah untuk menganalisis dan mengetahui secara parsial dan simultan pengaruh kepemimpinan kepala sekolah, lingkungan kerja, dan motivasi terhadap profesionalisme guru PAUD.Penelitian ini melibatkan seluruh guru PAUD di Kecamatan Subang, Kabupaten Subang dengan jumlah populasi 238 orang. Dengan rumus slovin sebagai metode pengambilan sampel dan menggunakan metode sampling acak proporsional, sehingga didapatkan 150 guru PAUD yang dijadikan sebagai sampel dalam penelitian ini. Metode penelitian ini merupakan penelitian kuantitatif deskriptif dan verifikatif, sedangkan regresi linier berganda digunakan sebagai alat analisa data.. Pengujian hipotesis dengan hasil yang menunjukan (1)Kepemimpinan kepala sekolah memberikan pengaruh positif serta signifikan pada profesionalisme guru PAUD, (2) Lingkungan kerja mempunyai pengaruh positif dan signifikan pada profesionalisme guru PAUD, (3) Motivasi berpengaruh positif serta signifikan terhadap profesionalisme guru $P A U D$ (4) Kepala sekolah dalam melaksanakan kepemimpinannya, lingkungan kerja serta motivasi secara simultan memberi pengaruh positif serta signifikan pada profesionalisme guru PAUD sebesar 64,7\%, dan sisanya dipengaruhi factor lain diluar penelitian ini.
\end{abstract}

Kata kunci: Kepemimpinan Kepala Sekolah, Lingkungan Kerja, Motivasi, Profesionalisme Guru PAUD

\section{PENDAHULUAN}

Selaras dengan visi Indonesia 2045 maka dalam Undang-undang Republik Indonesia nomor 20 tahun 2003 pada Bab II pasal 3 yang menyatakan, "Pendidikan nasional berfungsi mengembangkan kemampuan dan membentuk watak serta peradaban bangsa yang bermartabat dalam rangka mencerdaskan bangsa, bertujuan untuk berkembangnya potensi peserta didik agar menjadi manusia yang beriman dan bertakwa kepada Tuhan Yang Maha Esa, berakhlak mulia, sehat, berilmu, cakap, kreatif, mandiri, dan menjadi warga negara yang demokratis serta bertanggung jawab."

Peranan guru sangat penting dalam peningkatan kualitas pendidikan. Tiadanya peran guru yang optimal, tidak akan terjadi proses pembelajaran yang berjalan dengan baik. Maka, guru, salah satu faktor penting 
untuk meningkatkan kualitas pendidikan, mutu guru harus diperhatikan. Salah satu faktor yang yang sanat signifikan, menjadi bagian terpenting dalam proses belajar dan mengajar, baik pendidkan fornal maupun nonfrmal. Demikianlah, dalam setiap hal yang menjadi upaya peningkatan kualitas dalam pendidikan, eksistensi guru Oleh sebab itu, dalam setiap upaya peningkatan kualitas pendidikan di tanah air, guru tidak dapat dilepaskan dari berbagai hal yang berkaitan dengan eksistensi mereka.

Undang-undang No. 14/2005, menjelaskan guru dan juga dosen merupakan komponen yang harus ada dalam pendidikann. Guru dan perannya tidak bisa diabaikan.

Pendidikan Anak Usia Dini [PAUD] adalah Pendidikan yang dilaksanakan untuk membentuk perilaku atau karakter melalui pembiasaan di kehidupan sehari-hari seperti menjaga kebersihan dan keamanan, mandiri, sopan santun, berani, tanggung jawab, dan pengendalian diri. PAUD merupakan lembaga pendidikan yang menjembatani antara keluarga dan lingkungan lainnya. Pendidikan anak di usia Dini ini merupakan pemberian rangsangan sensorik dan motorik sebagai upaya untuk mengembangkan imajinasi dan wawasan agar anak tumbuh dan berkembang dengan baik sebagai persiapan menempuh pendidikan ke jenjang Pendidikan Dasar.

Kecamatan Subang merupakan salah satu kecamatan di Kabupaten Subang memiliki lembaga pendidikan anak usia dini / kober sebanyak 62 lembaga yang terdiri dari 238 org guru. Dalam hal ini kecamatan Subang, sebagai kecamatan penyelenggara PAUD terbanyak di kabupaten Subang.

Dalam mewujudkan PAUD yang berkualitas, maka diperlukan para pendidik dan tenaga kependidikan (PTK) yang memiliki kemampuan mumpuni terutama dalam mengelola pembelajaran, menyiapkan media pendukung yang relevan serta menguasai metode pembelajaran yang berpusat pada anak. Untuk mendapatkan kemampuan tersebut maka para pendidik dapat mengikuti berbagai pelatihan baik daring ataupun luring, kegiatan pada gugus PAUD dengan sesama pendidik atau kegitan peningaktan kompetensi lainnya yang diselenggarakan pemerintah ataupun HIMPAUDI.

Gambaran umum tenaga pendidik PAUD di Kecamatan Subang didominasi oleh jenjang pendidikan SMA/sederajat dan D4/S1. Dengan kualifikasi pendidikan yang beragam tersebut maka memberikan dampak yang berbeda dalam melaksaanakan proses pembelajaran disatuan pendidikan, tergantung pada pengalaman dan pelatihan yang diikutinya. Namun tidak menutup kemungkinan dalam pelaksanaan pengelolaan pembelajaran masih ada pendidik yang kurang optimal mengelola pembelajaran di satuan pendidikan. Akan tetapi secara umum tidak mengurangi profesionalisme guru dalam menjalankan tugasnya di satuan pendidikan. Pendidik PAUD yang profesional dalam mengelola pembelajaran disatauan pendidikan harus mampu mendorong pembelajaran yang berpusat pada anak dan membuat proses pembelajaran yang menyenangkan. 
Berdasarkan hasil wawancara dengan guru dan pengelola PAUD di kecamatan Subang, kabupaten Subang, diketahui bahwa profesionalisme guru PAUD secara umum mencapai hasil yang optimal terutama dalam empat kompetensi keguruan yaitu kompetensi kepribadian, kompetensi paedagogik, kompetensi sosial, dan kompetensi profesional. Kondisi seperti ini memiliki keterkaitan terhadap proses dukungan kepemimpinan Kepala Sekolah, lingkungan kerja. Seorang pendidik yang profesional tentunya harus dibarengi dengan kemampuan dan keahlian dalam mengelola pembelajaran disatuan pendidikan. Kondisi seperti ini akan mendorong dan memotivasi pendidik untuk mengembangkan kemampuan yang dimilikinya sehingga mampu diterapkan dalam mengelola pembelajaran dengan kata lain seorang pendidik yang profesional harus memiliki motivasi yang tinggi dalam mengelola pembelajaran,

Tujuan dari penelitian ini adalah untuk mengetahui dan mengkaji, (1) bagaimana kepemimpinan Kepala Sekolah, kondisi lingkungan kerja, motivasi dan profesionalisme guru PAUD di kecamatan Subang. (2) Seberapa besar pengaruh kepemimpinan kepala sekolah terhadap profesionalisme guru PAUD di kecamatan Subang. (3) Seberapa besar pengaruh lingkungan kerja terhadap profesionalisme guru PAUD di kecamatan Subang. (4) Seberapa besar pengaruh motivasi terhadap profesionalisme guru PAUD di kecamatan Subang. (5) Seberapa besar pengaruh kepemimpinan Kepala Sekolah, lingkungan kerja dan motivasi secara simultan pada profesionalisme guru PAUD di kecamatan Subang.

\section{TINJAUAN PUSTAKA}

\section{Kepemimpinan Kepala Sekolah}

Kepemimpinan merupakan kegiatan untuk mempengaruhi orang-orang yang diarahkan terhadap pencapaian tujuan organisasi [1]. Kepemimpinan sebagai kemampuan dan kesiapan seseorang untuk mengarahkan, membimbing, atau mengatur orang lain [2]. Dengan demikian kepemimpinan merupakan ruh yang menjadi pusat sumber gerak dalam mencapai tujuan organisasi. Dengan demikian kepemimpinan yang berkaitan dengan kepala sekolah disatuan pendidikan PAUD, diperperlukan kepala sekolah yang mampu mendorong kinerja para guru dengan dadn memberikan contoh sehingga menjadai tauladan para pendidikan di satuan pendidikan.

Secara umum bahwa kepemimpinan kepala sekolah tersebut merupakan kemampuan secara individu sebagai seorang pempimpin disekolah untuk mempengaruhi dan mengarahkan para guru untuk mencapai tujuan yang ditetapkan. Gambaran indikator kepemimpinan kepala sekolah [3] sebagai berikut :
a) mampu mempengaruhi
b) mampu mengarahkan
c) mampu melakukan pembimbing
d) mampu mengatur
e) memiliki kemampuan endorong kinerja para guru 
f) Memiliki rasa bersahabat dan dekat dengan para guru

g) memiliki Penuh pertimbangan

\section{Lingkungan Kerja}

Lingkungan kerja adalah segala sesuatu yang ada disekitar para pekerja yang dapat mempengaruhi dirinya dalam menjalankan tugas-tugas yang diembankan [4]. Lingkungan kerja merupakan lingkungan dimana para karyawan tersebut bekerja [5].

Lingkungan kerja adalah lingkungan yang mempengaruhi karyawan dalam melaksanakan tugas-tugasnya. Indikatorindikator yang mempengaruhi lingkungan kerja yaitu:

a) Bangunan yang menarik dan nyaman

b) Peralatan yang memadai

c) Adanya tempat rekreasi, tempat istirahat, dan tempat olahraga

d) Adanya sarana transportasi

e) Strategis

f) Perasaan aman

g) Loyalitas yang bersifat vertikal dan horizontal

\section{Motivasi Kerja}

Motivasi kerja diartikan sebagai sesuatu yang menimbulkan dorongan atau semangat kerja atau pendorong semangat kerja [6]. Motivasi adalah suatu proses yang menerangkan intensitas, arah, dan ketekunan seorang individu untuk mencapai tujuannya [6]. Pendapat lain menyebutkan bahwa motivasi merupakan hal yang menyebabkan, menyalurkan, dan mendukung perilaku manusia, supaya mau bekerja giat dan antusias mencapai hasil yang optimal [7]. Pendapat lain menyebutkan bahwa motivasi merupakan daya pendorong yang mengakibatkan seseorang anggota organisasi mau dan rela untuk mengerahkan kemampuan dalam bentuk keahlian atau keterampilan, tenaga dan waktunya untuk menyelenggarakan berbagai kegiatan yang menjadi tanggung jawabnya dan menunaikan kewajibannya, dalam rangka pencapaian tujuan dan berbagai sasaran organisasi yang telah ditentukan sebelumnya [8]

Dari hasil penelaahn terhadap definisi motivasi kerja yang telah diuraikan, dapat simpulkan bahwa motivasi kerja adalah merupakan faktor pendorong yang mengakibatkan seseorang mengerahkan semua potensi untuk melaksanakan aktivitas atau kegiatan yang menjadi tanggung jawabnya.

Adapun indikator motivasi yang menjadi rujukan para pendidik dan tenaga kependidikan di satuan pendidikan dikategorikan sebagai berikut:

a) Hasil kerja yang dicapai seseorang dalam melaksanakan tugas-tugasnya (Achievement)

b) Pengakuan yang diberikan kepada tenaga kerja atas hasil kerja. (Recognition)

c) Tantangan yang dirasakan tenaga kerja dari pekerjaannya (Work it self)

d) Tanggung jawab diberikan kepada seorang tenaga kerja atas hasul kerja. (Responsibilities) 
e) kesempatan kenaikan pangkat. (Advancement)

f) kemungkinan tenaga kerja berpeluang maju dan berkembang dalam pekerjaannya. (Growth) [9]

\section{Profesionalisme Guru}

Profesionalisme guru dalam proses pembelajaran harus mengacu pada tiga kemampuan dasar yaitu pengetahuan, keteampilan dan integritas, sehingga mampu mencapaii tujuan yang ditetapkan. Hal tersebut sejalan dengan pendapat para hali yang mendefinisikan profesionalisme diartikan sebagai keandalan dalam pelaksanaan tugas sehingga terlaksana dengan mutu yang baik, waktu yang tepat, cermat dan dengan prosedur yang mudah dipahami dan diikuti oleh pelanggan atau masyarakat [8]. Professional itu terdiri dari tiga unsur, yaitu knowledge, skill, integrity, dan selanjutnya ketiga unsur tersebut harus dilandasi dengan iman yang teguh, pandai bersyukur, serta kesediaan untuk belajar terus-menerus [10].

\section{METODE}

Metode yang digunakan dalam peneliana adalah metode deskriptif dan verifikatif dengan pendekatan penelitian kuantitatif. Pendekatan deskriptif digunakan untuk mengetahui bagaimana tanggapan konsumen mengenai Kepemimpinan Kepala Sekolah, Lingkungan Kerja, Motivasi, dan Profesionalisme Guru PAUD di Kecamatan Subang, Kabupaten Garut. Sedang pendekatan verifikatif menggunakan regresi berganda untuk mengetahui pengaruh
Kepemimpinan Kepala Sekolah, Lingkungan Kerja, dan Motivasi terhadap Profesionalisme Guru PAUD di Kecamatan Subang Kabupaten Subang.

Data penelitian ini diperoleh dari lokasi penelitian yang diamati oleh peneliti yaitu di Kecamatan Subang Kabupaten Subang, yang dikumpulkan melalui instrumen penelitian berbentuk kuesioner terhadap guru PAUD yang tersebar pada 64 PAUD yang terdapat pada 8 desa dari 10 desa, dengan jumlah 238 orang guru. Metode pengambilan sampel dalam penelitian ini dengan menggunakan rumus Slovin maka ditentukan ukuran sampel sejumlah 150 guru PAUD [11].

Operasionalisasi variabel dalam penelitian ini melingkupi variabel independen dan variabel dependen.Variabel independen dalam penelitian ini meliputi variabel kepemimpinan kepala sekolah (X1), lingkungan kerja (X2), motivasi (X3) dan profesionalisme guru (Y). Untuk mengukur validitas instrumen kepemimpinan kepala sekolah, lingkungan kerja, motivasi dan profesionalisme guru dilakukan uji coba instrumen dengan menggunakan guru PAUD sebagai responden. Validitas instrumen keempat variabel dicari dengan cara menghitungnya dalam program SPSS 23.0, dengan ketentuan Jika $r_{\text {hitung }} \geq r_{\text {tabel }}$ maka instrumen item pertanyaan dinyatakan valid, dan Jika $r_{\text {hitung }} \leq r_{\text {tabel }}$ maka instrumen item pertanyaan dinyatakan tidak valid.

Suatu kuesioner dikatakan reliable atau handal jika jawaban seseorang konsisten terhadap pertanyaan yang diajukan dengan melihat hasil cronbach alpha, dengan ketentuan: 
Tabel 1 Tingkat Reliabilitas

\begin{tabular}{|c|c|}
\hline Cronbach Alpha & Tingkat Reliabilitas \\
\hline$\leq 0,5$ & Rendah \\
\hline$\geq 0,6$ & Mencukupi \\
\hline$\geq 0,7$ & Mencukupi / Sedang \\
\hline$\geq 0,8$ & Tinggi \\
\hline$\geq 0,9$ & Sempurna \\
\hline
\end{tabular}

Data yang berskala ordinal (likert) tidak dapat langsung dianalisis dengan statistik parametrik, seperti regresi berganda oleh karena itu, terlebih dahulu harus menaikan data ordinal menjadi data interval dengan menggunakan Method of Successive Interval (MSI) yang menunjukkan jarak antara satu data dengan data yang lain mempunyai bobot yang sama.

Tahap selanjutnya adalah dilakukan uji asumsi klasik sebelum dilaksanakan uji hipotesis, yang merupakan salah satu syarat pada penelitian kuantitatif.

Adapun tujuan dilakukan kegiatan uji asumsi klasik untuk dapat memberikan kepastian bahwa persamaan regresi yang diperoleh dari hasil penelitian memiliki ketepatan dalam beberapa hal yaitu estimasi, tidak bias, dan konsisten.

Sebelum peneliti melakukan analisis regresi, terlebih dahulu dilakukan pengujian asumsi. Ketika hasil uji asumsi klasik dinyatakan tidak sesuai dengan yang diharapkan, maka akan timbul berbagai reaksi yang beragam.

Dari gambaran tujuan serta hipotesis penelitian, maka model analisis yang digunakan yaitu jenis analisis regresi linier berganda. Alasan penggunaan model analisis ini adalah untuk mengetahui hubungan antara variabel-variabel terikat, (X1) antara kepemimpinan kepala sekolah, (X2) lingkungan kerja , serta (X3) motivasi terhadap (Y) profesionalisme guru. Rumus analisis regresi berganda [12] menggunakan: $\mathrm{Y}=\mathrm{a}+\mathrm{b} 1 \mathrm{X} 1+\mathrm{b} 2 \mathrm{X} 2+\mathrm{b} 3 \mathrm{X} 3$

Untuk menghitung koefisien korelasi dapat digunakan rumus koefisien korelasi Product Moment Pearson, sebagai berikut:

$r=\frac{\mathrm{n} \sum \mathrm{xy}-\left(\sum x\right)\left(\sum y\right)}{\sqrt{\left(\mathrm{n} \sum x^{2}\right)-\left(\sum x\right)^{2}\left(\mathrm{n} \sum Y^{2}-\left(\sum Y\right)^{2}\right)}}$

Sedangkan $\left(\mathrm{R}^{2}\right)$ Koefisien determinasi dilakukan untuk mengukur seberapa jauh kemampuan model menerangkan variasi variabel independen. Ketika nilai $\mathrm{R}^{2}$ diperoleh kecil berarti kemampuan variabelvariabel independen dalam menjelaskan variasi variabel dependen sangat terbatas, namun ketika nilai $\mathrm{R}^{2}$ yang diperoleh mendekati satu maka variabel-variabel independen memberikan hampir semua informasi dibutuhkan guna mempredidksi variabel dependen [12].

Adapun rumus yang digunakan (Sugiyono,2013):

$\mathrm{KD}=\mathrm{r}^{2} \times 100 \%$

\section{HASIL DAN PEMBAHASAN}

Hasil penelitian yang telah dilakukan dengan menggunakan program SPSS (Statistical Product and Service Solution). Tahapan yang 
dilakukan dimulai dari uji validitas dan uji reliabilitas, selanjutnaya analisis deskriptif untuk mengetahui persepsi masing-masing responden terhadap variabel penelitian. Analisis inferensial dengan menggunakan analisis regresi berganda (multiple regression).

Adapun variabel penelitian mencakup (X1) Kepemimpinan Kepala Sekolah, (X2) Lingkungan Kerja, (X3) Motivasi dan Y Profesionalisme Guru, dengan responden 150 orang dengan karakteristik berdasarkan jenis kelamin, usia, pendidkan dan masa kerja. $89 \%$ guru wanita dan $11 \%$ guru pria. Sebagian besar berada pada rentang umur 31-40 tahun sebesar 50\% dan diikuti oleh rentang usia 4150 sebesar 30\% dan rentang 21-30 sebesar $13 \%$ dan sisanya, sebesar $7 \%$ sedangkan sisanya usia diatas 50 tahun dan dibawah 20 Tahun. Didominasi oleh lulusan SMA dengan jumlah $61 \%$ selanjutnya diikuti oleh lulusan S1 sebesar 29\%, dan sisanya $10 \%$ untuk Diploma, baik diploma 1, 2 maupun 3. Dan telah mengabdi selama kurang lebih 7-9 tahun dengan persentase $61 \%$, masa kerja dari 4-6 tahun tahun sebesar $34 \%$ dan 1-3 tahun $17 \%$, sisanya sebesar 3\% memiliki masa kerja yang masih relative kurang dari 1 tahun, sementara masa kerja di atas 9 tahun sebesar $5 \%$.

Uji validitas untuk semua variable dalam peneltian ini diperoleh nilain $r_{\text {hitung }}>r_{\text {tabel }}$ dengan demikian diharapkan semua pertanyaan diputuskan signifikan serta memiliki validitas baik. Demikian juga dengan uji reliabilitas memiliki nilai cronbach alpha di atas 0,6 yang berarti instrument memiliki hasil yang reliabel, sehingga instrument atau selurung angket/kuisioner dalam penelitian ini termasuk kepada instrumen reliabel dan konsisten.

\section{Analisis Deskripsi}

Analisis deskripsi berdasarkan rekapitulasi kuisioner yang disebarkan kepada responden dihasilkan sebagai berikut:

Tabel 2: Hasil Analisis Deskripsi

\begin{tabular}{|c|c|c|c|c|}
\hline $\begin{array}{l}\text { No. } \\
\text { Var }\end{array}$ & Nama Variabel & $\begin{array}{c}\text { Hasil } \\
\text { Analisis } \\
\text { Deskripsi }\end{array}$ & $\begin{array}{l}\text { Nilai Indikator } \\
\text { Tertinggi }\end{array}$ & $\begin{array}{l}\text { Nilai Indikator } \\
\text { Terendah }\end{array}$ \\
\hline 1 & $\begin{array}{l}\text { Kepemimpinan kepala } \\
\text { Sekolah }\end{array}$ & Sangat baik & $\begin{array}{l}\text { Kemampuan } \\
\text { mempengaruhi }\end{array}$ & $\begin{array}{l}\text { Pertimbangan dalam } \\
\text { pengambilan } \\
\text { keputusan }\end{array}$ \\
\hline 2 & Lingkungan Kerja & baik & $\begin{array}{l}\text { Pihak Sekolah telah } \\
\text { menyediakan alat tulis } \\
\text { mengajar yang } \\
\text { memadai }\end{array}$ & $\begin{array}{l}\text { Pihak Sekolah } \\
\text { menyediakan fasilitas } \\
\text { tempat rehat dan } \\
\text { olahraga yang } \\
\text { memadai }\end{array}$ \\
\hline 3 & Motivasi & Sangat baik & $\begin{array}{l}\text { menyukai tantangan } \\
\text { yang harus dihadapi } \\
\text { pada setiap tugas } \\
\text { pekerjaan }\end{array}$ & $\begin{array}{l}\text { senang untuk } \\
\text { mencoba hal-hal baru } \\
\text { yang relevan dengan } \\
\text { pekerjaan }\end{array}$ \\
\hline 4 & Profesionalisme Guru & baik & $\begin{array}{l}\text { Pendidikan penting dan } \\
\text { dapat menunjang bagi } \\
\text { Profesi yang saya jalani } \\
\text { sebagai guru }\end{array}$ & $\begin{array}{l}\text { cepat beradaptasi di } \\
\text { tempat bekerja }\end{array}$ \\
\hline
\end{tabular}




\section{Analisis Verifikatif (Uji Regresi Berganda)}

Untuk mengetahui apakah data yang diambil berasal dari populasi yang berdistribusi normal maka dilakukan uji normalitas. Adapun kegiatan analisis kenormalan menggunakan metode Kolmogorov-Smirnov mensyaratkan kurva normal apabila nilai Asymp. Sig. $(0,120)$ berada di atas batas maximum error, yaitu 0,05 , maka data di atas berdistribusi normal.

Sedangkan kegiatan uji heteroskedastitas memiliki tujuan untuk menguji apakah dalam model regresi terjadi ketidaksamaan varians dari residual satu pengamatan ke pengamatan yang lain. Berdasarkan output uji dapat dilihat bahwa terdapat korelasi yang tidak signifikan. Hal ini dilihat dari nilai p-value (Sig) yang lebih besar dari 0,05. Sehingga dapat disimpulkan tidak terjadi heteroskedastisitas pada model regresi.

Tahap uji multikolinieritas dilakukan dengan menggunakan Variance Inflation Factors (VIF). Berdasarkan output uji diperoleh bahwa hasil nilai VIF kurang dari 10, dengan demikian disimpulkan bahwa tidak terdapat multikolinearitas dalam data penelitian.

Dari hasil perhitungan pada tabel di atas, diperoleh bentuk bentuk persamaan regresi linier berganda sebagai berikut :

$Y=0,272+0,626 X_{1}+0,065 X_{2}+0,138 X_{3}$

Dari persamaan regresi linier berganda tersebut diperoleh nilai konstanta sebesar 0,272. Artinya, jika variabel Profesionalisme Guru tidak dipengaruhi oleh ketiga variabel bebasnya yaitu (X1) atau kepemimpinan Kepala Sekolah, (X2) Lingkungan Kerja dan (x3) Motivasi memiliki nilai nol, maka besarnya rata-rata Profesionalisme Guru akan memiliki bobot nilai 0,272 .

Gunaa memperoleh gambaran tingakt signifikan atau tidaknya suatu pengaruh dari variabel-variabel bebas secara bersama-sama atas suatu variabel tidak bebas maka dilakukan uji F. Hasil pengujian memberikan gambaran bahwa nilai $\mathrm{F}$ hitung sebesar 89,110 . Karena nilai $F$ hitung $(89,110)>F$ tabel $(2,667)$, dengan demikian Ho ditolak. Kesimpulan yang diperoleh bahwa secara simultan terdapat pengaruh yang signifikan dari Kepemimpinan Kepala Sekolah, Lingkungan Kerja dan Motivasi terhadap Profesionalisme Guru.

Sedangkan kegiatan uji $\mathrm{t}$ digunakan untuk mengetahui signifikan atau tidaknya suatu pengaruh dari variabel-variabel bebas secara parsial atas suatu variabel tidak bebas.

Hasil yang diperoleh tergamabr sebagai berikut:

1. Variabel (X1) kepemimpinan kepala sekolah memiliki nilai sig lebih kecil dari 0,05 . Karena nilai sig $(0,000)<0,05$, degnan demikian Ho ditolak. Kesimpulanyang diperoleh bahwa secara parsial terdapat pengaruh signifikan dari Kepemimpinan Kepala Sekolah terhadap Profesionalisme Guru.

2. Variabel (X2) lingkungan kerja, diperoleh nilai sig lebih kecil dari 0,05. Karena nilai sig $(0,040)<0,05$, dengan demikian Ho ditolak. Hal ini berarti secara parsial terdapat pengaruh signifikan dari 
Lingkungan kerja terhadap

Profesionalisme Guru.

3. Variabel (X3) motivasi diperoleh nilai sig lebih kecil dari 0,05. Karena nilai sig $(0,003)<0,05$, dengan demikian Ho ditolak. Kesimpulan yang bahwa secara parsial terdapat pengaruh signifikan dari Motivasi terhadap Profesionalisme Guru.

Analisis korelasi berganda dengan menggunakan output software SPSS untuk nilai koefisiesn korelasi adalahsebesar 0,804. Dengan demikian diperoleh gambaran bahwa terdapat hubungan yang kuat antara Kepemimpinan Kepala Sekolah, Lingkungan Kerja dan Motivasi terhadap Profesionalisme Guru.

Adapun besarnya pengaruh kepemimpinan kepala sekolah, lingkungan kerja, dan motivasi terhadap Profesionalisme Guru dapat ditunjukkan oleh koefisien determinasi:

$$
\begin{aligned}
\mathrm{KD} & =\mathrm{R}^{2} \times 100 \% \\
& =(0,804)^{2} \times 100 \% \\
& =64,7 \%
\end{aligned}
$$

Hal ini berarti variabel Kepemimpinan Kepala Sekolah, Lingkungan Kerja dan Motivasi memberikan pengaruh sebesar $64,7 \%$ terhadap Profesionalisme Guru. Sedangkan sisanya sebesar 35,3\% merupakan kontribusi variabel lain selain Kepemimpinan Kepala Sekolah, Lingkungan Kerja dan Motivasi.

\section{KESIMPULAN}

1. Analisis deskriptif pada variabel Kepemimpinan Kepala Sekolah, Lingkungan kerja, Motivasi dan Profesionalisme secara rata rata berada pada kategori baik.
2. Terdapat hubungan dan pengaruh positif dan signifikan dari kepemimpinan kepala sekolah terhadap profesionalisme guru;

3. Terdapat hubungan positif, searah dan pengaruh yang signifikan antara variabel lingkungan kerja terhadap profesionalisme guru PAUD di kecamatan Subang kabupaten Subang

4. Terdapat hubungan positif, searah dan signifikan antara motivasi terhadap profesionalisme guru PAUD,

5. Kepemimpinan kepala sekolah, lingkungan kerja dan motivasi secara bersama-sama (simultan) mempunyai pengaruh yang signifikan terhadap profesionalisme guru PAUD di kecamatan Subang kabupaten Subang

\section{DAFTAR PUSTAKA}

[1] M., Mulyasa, E. (2007). Standar kompetensi dan sertifikasi guru. Indonesia: Remaja Rosdakarya.

[2] Soewadji Lazaruth. (2004). Kepala Sekolah dan Tanggung Jawabnya. Yogyakarta: Kanisius, Sriningsih

[3] Endang Poerwanti, Beti Istanti Suwandayani, • (2020), Manajemen Sekolah Dasar Unggul, UMMPress, ISBN:9789797963613, 9797963616

[4] Alex S N Alex S Nitisemito, (2018) MANAJEMEN PERSONALIA, Ghalia, Indonesia.

[5] Ahyari, Agus. (2002). Manajemen Produksi Perencanaan Sistem Produksi. Yogyakarta: BPFE.

[6] Hani Handoko, (2020), Manajemen Personalia \& Sumberdaya Manusia, Edisi kedua, BPFE UGM Yogyakarta 
[7] Hasibuan, Malayu S.P. (2016). Manajemen Sumber Daya Manusia. Edisi Revisi, Cetakan Kedua. PT. Refika Aditama: Bandung

[8] Siagian. Sondang P. 2012. Manajemen Sumber Daya Manusia, Bumi Aksara. Jakarta

[9] Herzberg, Frederick. 2011. Herzberges Motivation-Hygiene Theory and Job Satisfaction in The Malaysian Retail Sector: The Mediating Effect Of Love Money. Sunway University Malaysia: Teck Hang Tan and Amna Waheed
[10] Moeljono, Djokosantoso. (2005). Budaya Organisasi dalam Tantangan. Jakarta: PT. Elex Media Komputindo.

[11] Husein, Umar. 2008. Metode Penelitian Untuk Skripsi dan Tesis Bisnis.Jakarta. PT Rajagrafindo Persada

[12] Ghozali, Imam. 2011. "Aplikasi Analisis Multivariate Dengan Program SPSS". Semarang: Badan Penerbit Universitas Diponegoro.

[13] Sugiyono. (2015), Metode penelitian kualitatif dan kuantitatif, Alfabet, Bandung. 